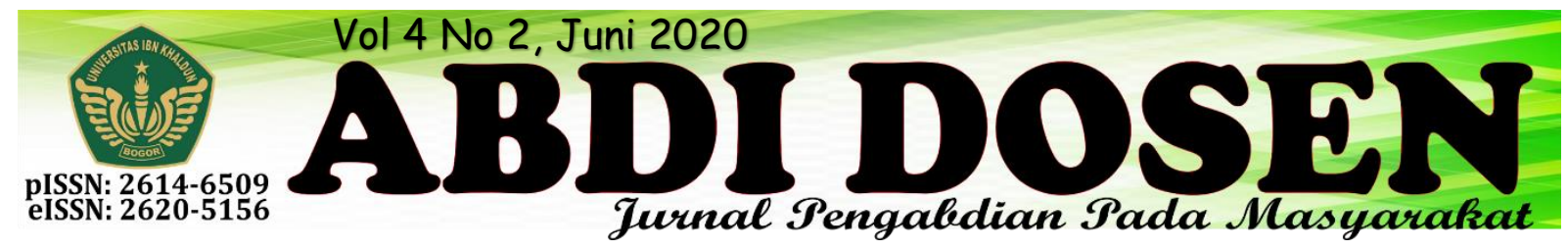

\title{
PENINGKATAN SOFT SKILL MASYARAKAT DESA LEUWIMEKAR MELALUI PEMANFAATAN TEKNOLOGI, HIDROPONIK DAN DESIMINASI EKONOMI KREATIF BERBASIS DAUR ULANG SAMPAH
}

\author{
Fitrah Satrya Fajar Kusumah ${ }^{1}$, Salati Asmahasanah ${ }^{2}$, Nadia Sofwah ${ }^{3}$ \\ fitrah.satry@gmail.com ${ }^{1}$ \\ salati.asmahasanah@gmail.com ${ }^{2}$ \\ nadiasofwah.wow@gmail.com ${ }^{3}$ \\ Fakultas Teknik dan Sains ${ }^{1}$, Fakultas Agama Islam² ${ }^{2}$ Mahasiswa KKN Kelompok 03\&04 Tahun $2019^{3}$
}

\begin{abstract}
ABSTRAK
KKN Tematik Terintegrasi merupakan KKN yang orientasi program terfokus pada bidang tertentu sesuai dengan permasalahan kemasyarakatan yang ada. KKN memiliki tujuan memahami kondisi masyarakat. Tujuan diadakannya KKN yaitu untuk memajukan desa tersebut baik dalam bidang ekonomi, pendidikan, sosial, dan lainnya. Mahasiswa KKN UIKA yang tergabung dari beberapa jurusan bisa membantu masyarakat dengan kemampuannya masing-masing. Pelaksanaan KKN dimulai dari tanggal 6 Agustus 2019 sampai dengan 5 September 2019 di Desa Leuwimekar Kecamatan Leuwiliang Kabupaten Bogor. Program KKN kelompok 03 \& 04 di Desa Leuwimekar merupakan program yang lebih menekankan kepada kualitas sumber daya manusia. Beberapa Kegiatan yang menunjang peningkatan softskill masyarakat yaitu seperti pelatihan mengetik cepat, workshop media pembelajaran berbasis teknologi, pelatihan teknologi informasi, pemanfaatan barang-barang bekas, penyuluhan hidroponik, dan seminar investasi pasar modal syariah.
\end{abstract}

Kata Kunci: KKN Tematik Terintegrasi, Leuwimekar, Program Kerja.

\section{PENDAHULUAN}

\section{Latar Belakang}

Kuliah Kerja Nyata $(\mathrm{KKN})$ adalah bagian dari system perguruan Tinggi yang mengirim mahasiswanya untuk kuliah di luar kampus dan mengabdi di masyarakat, dalam hal ini mahasiswa ditempatkan pada suatu desa yang telah di tentukan oleh pihak Kampus untuk nanti bisa mengabdi dan memberikan peran serta manfaat pada kehidupan masyarakat di desa tersebut. Mahasiswa yang melaksanakan kegiatan KKN ini juga akan memanfaatkan potensi lokal baik dalam bidang Sumber Daya Alam (SDA) dan Sumber Daya Manusia
(SDM). Terkait KKN Universitas Ibn Khaldun Bogor tahun angkatan 2019 khususnya untuk kelompok 3 \& 4 yang di tempatkan di Desa Leuwimekar, Kecamatan Leuwiliang, Kabupaten Bogor. Kegiatan KKN ini juga menjadi implementasi mahasiswa dari Tri Dharma Perguruan Tinggi, yakni pendidikan, penelitian, dan pengabdian. Dengan melalui program KKN ini, tentunya mahasiswa berharap tidak hanya menjadikan dirinya sebagai kaum intelektual yang mengandalkan gagasan dan pemikiran kritisnya saja melainkan 
juga dapat membawa perubahan yang ke arah yang lebih baik bagi lingkungan masyarakat.

Berdasarkan hasil observasi dan analisis di Desa Leuwimekar Kecamatan Leuwiliang Kabupaten Bogor Provinsi Jawa Barat. Desa leuwimekar memiliki luas wilayah 244,1900 Ha, Koordinat Bujur 106.636345 Bujur Timur, Koordinat Lintang -6.570479 Lintang Selatan. Dengan Jumlah KK Laki-laki 4064 KK, KK Perempuan 497 KK, jumlah ini meningkat $39.01 \%$ dibandingkan tahun 2018. Serta memiliki batas wilayah sebelah utara Desa Leuwiliang, Sebelah Selatan Desa Barengkok, Sebelah Timur Kecamatan Cibungbulang, dan Sebelah Barat Desa Cibeber I dan Cibeber II. Memiliki luas sawah irigasi teknis 3,880000 Ha, perkebunan perorangan 7,540000 Ha. Memiliki 13 Rukun Warga, dan 46 Rukun Tetangga. Belum mempunyai Perpustakaan Desa, Taman Baca, Tempat Persalinan Balai Kesehatan Ibu anak. Sudah terjadi penyakit muntaber 4 kejadian selama tahun ini dan 5 kejadian kasus demam berdarah. Masih minimnya Lembaga Keuangan Syariah, Usaha Perkebunan.

\section{Permasalahan Yang Dihadapi}

Ada beberapa permasalahan yang terdapat di Desa Leuwimekar diantaranya :

1. Minimnya media pembelajaran untuk anak SD.

2. Kurangnya Kesadaran masyarakat terhadap lingkungan sehingga masih banyak yang membuang sampah ke sungai.

3. Kurangnya lapangan pekerjaan untuk ibu-ibu.

4. Tingkat Ekonomi Warga lemah

5. Kurangnya Pemahaman anak-anak SD terhadap komputer
6. Kurangnya lahan pertanian untuk bercocok tanam

\section{Solusi Yang Di Tawarkan}

Setelah memahami beberapa permasalahan yang terjadi di desa Leuwimekar, maka kami menawarkan beberapa solusi untuk memajukan desa leuwimekar, solusi nya yaitu :

1. Mengadakan workshop media pembelajaran berbasis teknologi untuk guru, diharapkan dengan diadakannya workshop ini guru-guru lebih kreatif dan inovatif dalam pembelajaran sehingga murid pun menjadi tidak jenuh dan bersemangat dalam belajar.

2. Dengan mengadakan pelatihan kewirausahaan yaitu dengan membuat bros dari barang-barang bekas dan memberikan motivasi berwirausaha serta trik trik penjualan sehingga dapat mengurangi sampah dan menambah pendapatan masyarakat.

3. Penyuluhan Hidroponik, diharapkan dengan adanya penyuluhan ini masyarakat bisa bercocok tanam walaupun hanya di pekarangan rumah karena hidroponik tidak membutuhkan tempat yang luas sehingga dengan tanaman hidroponik tersebut dapat memenuhi kebutuhan sayuran sehari hari ataupun untuk dijual kembali.

4. Pelatihan mengetik cepat, diharapkan dengan adanya pelatihan ini masyarakat mempunyai softskill tambahan dan jika bekerja dapat bekerja secara cepat.

5. Pelatihan Microsoft untuk anak anak SD, diharapkan setelah mengikuti pelatihan ini anak-anak sudah mempunyai dasar dalam mengenal computer sehingga dapat dengan mudah belajar Komputer.

6. Mengadakan seminar pasar modal syariah, dengan diadakannya kegiatan 
ini diharapkan masyarakat menjadi

paham mengenai investasi secara islami dan menghindari dari investasi bodong.

\section{METODE PENGABDIAN}

Tahapan Pelaksanaan untuk kegiatan ini sebagaimana terlihat pada bagan dibawah ini:

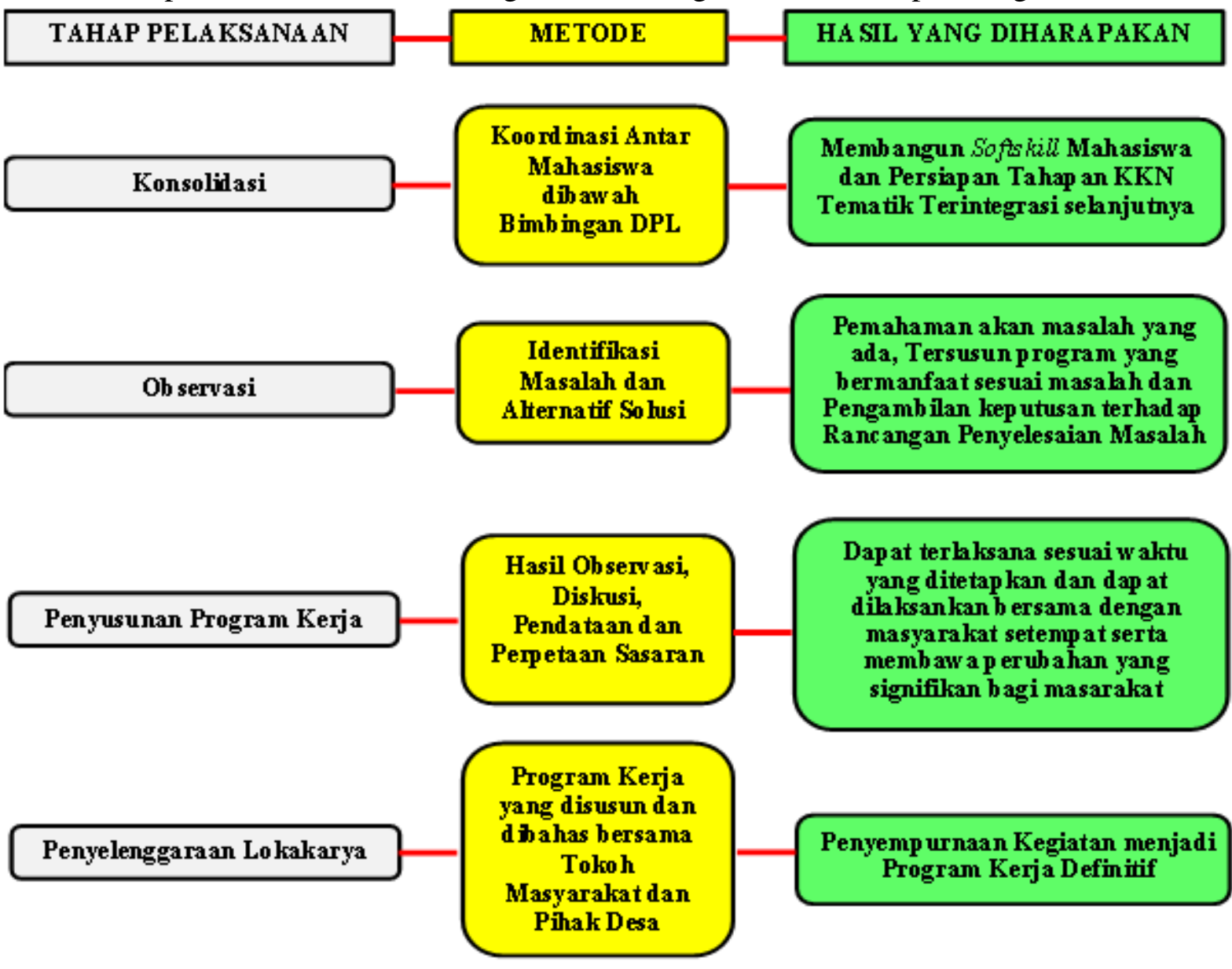

\section{Metode Pendekatan}

Ada beberapa metode pendekatan yang kami lakukan guna lebih dekat dengan masyarakat dan lebih memahami masyarakat sehingga jika sudah memahami maka lebih mudah dalam melaksanakan program kerja.

\section{Pendekatan Sosial}

Pendekatan sosial ini kami lakukan dengan mengadakan beberapa kegiatan seperti gotong royong, bersih-bersih dan senam pagi setiap hari minggu diharapkan dengan beberapa kegitan tersebut kami mahasiswa dapat lebih dekat denga masyarakat.

\section{Pendekatan Agama}

Ada beberapa cara yang kami lakukan seperti dengan mengikuti pengajian ibu-ibu majlis talim, pengajian bapak-bapak atau pengajian bersama anak yatim. Pendekatan ini perlu sebagai ajang silaturahmi dan saling mengenal.

3. Pendekatan Masyarakat

Pendekatan yang dimaksud yaitu pendekatan untuk memahami kebiasaan dan karakter masyarakat bisa dengan cara diskusi bareng dan mengikuti agenda yang ada di masyarakat.

4. Pendekatan Edukasi 
Masyarakat Desa leuwimekar memiliki kebudayaan dan latar belakang yang berbeda - beda, maka perlunya pendekatan edukasi ini agar lebih dekat dengan masyarakat dan mudah untuk mengadakan program kerja.

\section{Langkah Evaluasi}

Ada beberapa langkah evaluasi yang akan kami lakukan diantaranya yaitu

\section{HASIL DAN PEMBAHASAN}

1. Bidang Teknologi

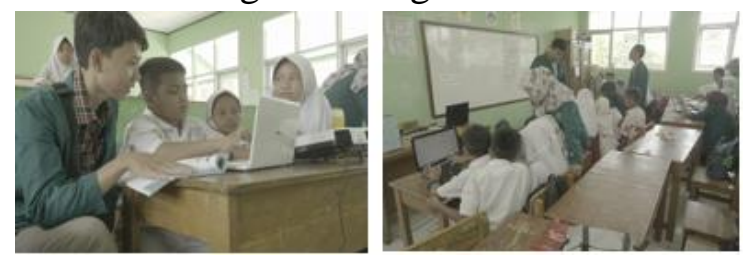

a. Pelatihan Microsoft

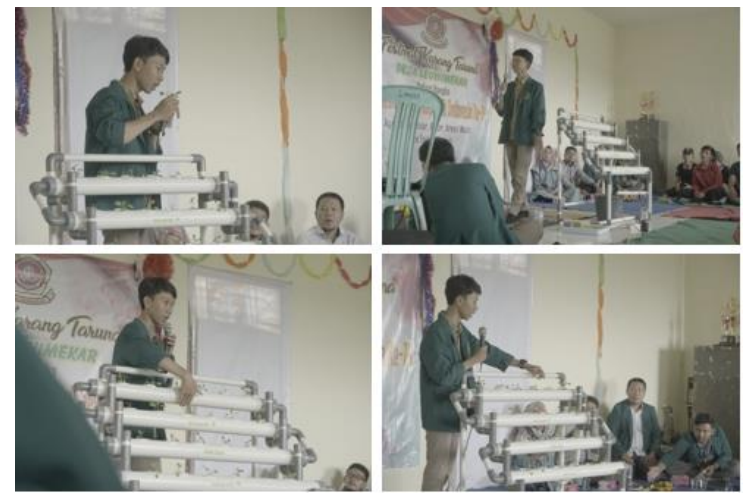

b. Hidroponik
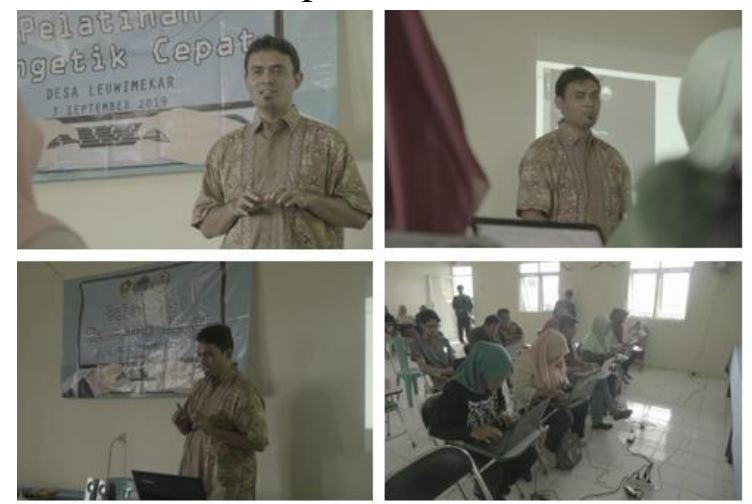

c. Pelatihan Mengetik Cepat
1. Evaluasi proses dan perencanaan Program Kerja KKN sehingga diharapkan dengan adanya evaluasi ini program kerja yang diharapkan dapat lebih terarah.

2. Evaluasi Hasil, evaluasi ini kita lakukan setiap kegiatan sudah dilaksanakan.

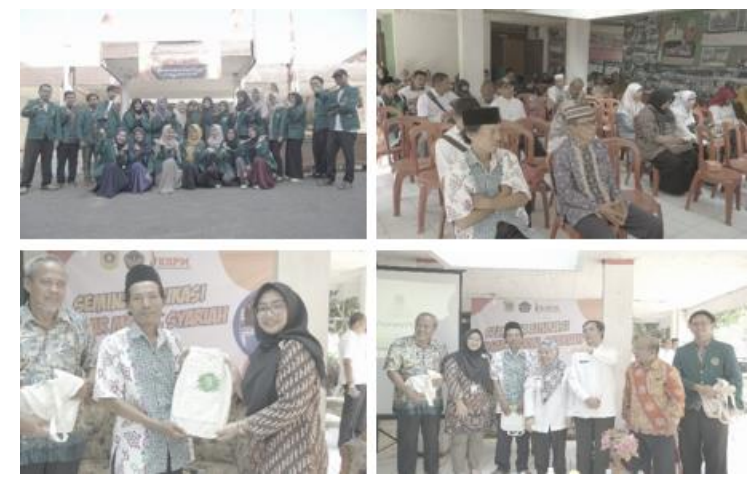

d. Workshop Media Pembelajaran Berbasis Teknologi

2. Bidang Ekonomi
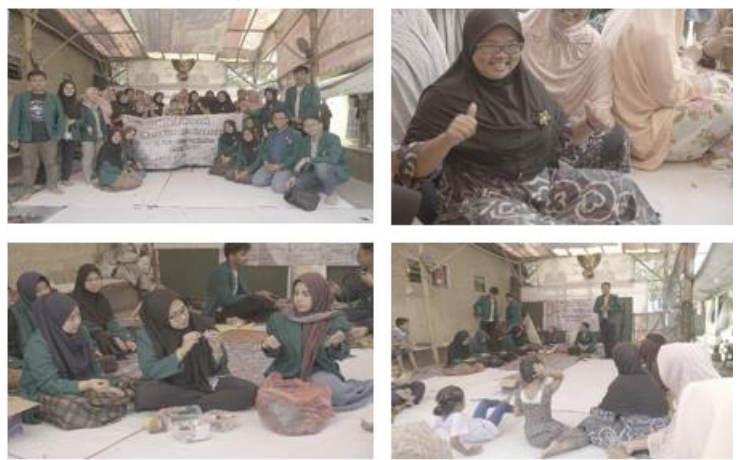

a. Seminar Pasar Modal Syariah 

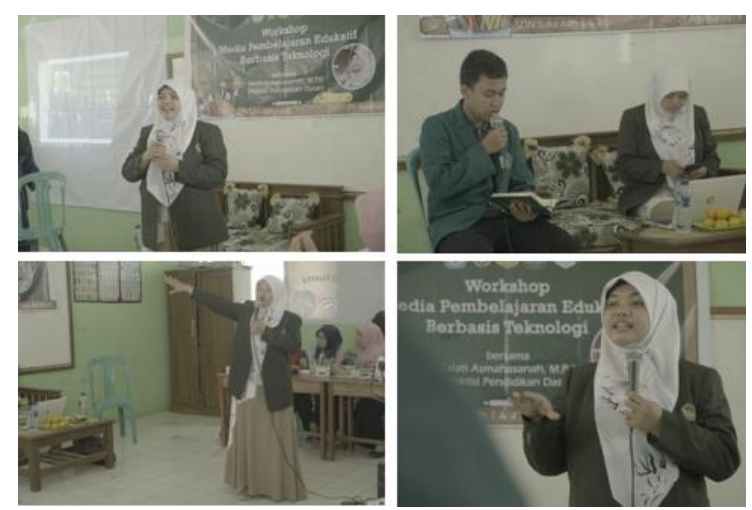

b. Pelatihan

Kewirausahaan

"MARKISA" (Mari Kita

Berwirausaha)

\section{KESIMPULAN}

Berdasarkan hasil kegiatan, pengamatan dan pelaksanaan program KKN Selama satu bulan ini, ada beberapa kesimpulan yang dapat kita jadikan pelajaran yaitu :

a. Keberhasilan KKN tidak terlepas dari kerjasama antar warga, RT, RW, Desa, Kecamatan dan Kampus UIKA. Sehingga dengan adanya kerjasama ini program dapat berjalan secara lancer.

b. Dengan adanya kami mahasiswa $\mathrm{KKN}$ UIKA masyarakat merasa terbantu dengan adanya tambahan informasi, sebagai contoh jika sebelumnya di kampong tersebut tidak mengadakan senam pagi setiap hari minggu maka setelah adanya mahasiswa senam pagi tersebut ada dan akan dilanjutkan ketika mahasiswa sudah selesai KKN.

c. Motivasi anak-anak untuk kuliah Menjadi Tinggi.

d. Permasalahan Sampah di sungai yang masih ada.

e. Masih kurangnya wirausaha disana sehingga Menjadi tugas kita bersama untuk membantu menerbitkan wirausaha muslim sejati.

Dengan beberapa kesimpulan diatas, maka dapat dinyatakan bahwa KKN kelompok $03 \& 04$ menjalankan Tugas KKN dengan baik dan lancer meskipun masih terdapat kekurangan dan kendala yang menghadang.

\section{Dampak Bagi Masyarakat}

Dalam Program kerja yang kami laksanakan ada beberapa dampak positif yang dirasakan masyarakat.

1. Bidang Teknologi

a. Pelatihan Microsoft, Anak-anak SD jadi mengetahui bagaimana cara mengetik di word, memperindah tulisan di word dan lain sebagainya, mereka Menjadi bersemangat untuk belajar computer.

b. Pelatihan mengetik cepat, dengan adanya pelatihan ini yang kebanyakan pesertanya dari pegawai Desa diharapkan dapat melayani masyarakat secara cepat dengan kemampuan mengetik cepat.

c. Workshop Media Pembelajaran Edukatif berbasis teknologi, dengan adanya workshop ini para guru Menjadi paham dan tahu mengenai media pembelajaran berbasis teknologi sehingga mempunyai alternatif dalam mengajar. 
2. Bidang Ekonomi

a. Pelatihan Kewirausahaan, dengan adanya program ini peserta yang mayoritas ibu-ibu Alhamdulillah sudah bisa membuat bros dan kemudian mengajarkan kembali ke ibuibu lain. Ibu-ibu sudah mendapatkan gambaran bagaimana cara menjual yang baik dan benar sehingga dapat menambah penghasilan mereka.

b. Seminar Pasar Modal Syariah, peserta seminar rata-rata dari pejabat kecamatan, desa,

\section{DAFTAR PUSTAKA}

(2019). Petunjuk Pelaksanaan KKN Tematik Terintegrasi 2019 Universitas Ibn Khaldun Bogor. Bogor : UIKA Press

Fathimah, A., Agnesia, U., Abdul, R. (2019). Pemberdayaan Masyarakat melalui Peningkatan Mutu Pendidikan, Ekonomi Dan Kesehatan Studi Kasus Desa Cibeber II. Jurnal Pengabdian Masyarakat, Vol. 03 No. 01, 01-07.

I. Sundarta, A. Sari and H. P. Wibowo, "Pengelolaan Limbah Organik Menjadi Kompos melalui Pembuatan kampung, atau RT / RW. Dengan adanya seminar ini masyarakat Menjadi melek investasi secara islami bahwa investasi itu luas dan aman dibandingkan dengan menyimpan uang di rumah.

3. Hidroponik, media cocok tanam dengan menggunakan paralon ini Menjadi alternatif jika warga ingin bercocok tanam namun tidak mempunyai lahan. Masyarakat Menjadi tahu bagaimana system hidroponik ini dari mulai semai sampai panen.

Tong Super" Jurnal Pengabdian Pada Masyarakat, 2018.

Prasetya, E. (2018). Pemberdayaan Masyarakat Tentang Kesehatan, Pendidikan dan Kreatifitas. Abdi Dosen: Jurnal Pengabdian Pada Masyarakat 2 (1), 19-25.

Sudrajat, A. 2008. Pendekatan Sosial. [Online] diakses pada Jum'at, 30 Agustus

2019.akhmadsudrajat.wordpress.com /2008/02/14/pendekatan-sosialdalam-kegiatan-kkn/amp/ 